\title{
Scissor excision of penile warts: case report
}

\section{P D SIMMONS* AND J P S THOMSON†}

From the *Department of Genitourinary Medicine, Eastern Hospital, and the *Department of Surgery, Hackney Hospital, London

SUMMARY The technique of fine scissor excision, which is used to treat anorectal warts, can be successfully applied to recalcitrant penile warts. A case is reported.

\section{Introduction}

Penile warts are a common management problem in genitourinary medicine, urology, and general surgery clinics. The difficulty in eradicating warts is emphasised by the number and variety of treatments available. We report here the successful use of a method previously reserved for anal warts.

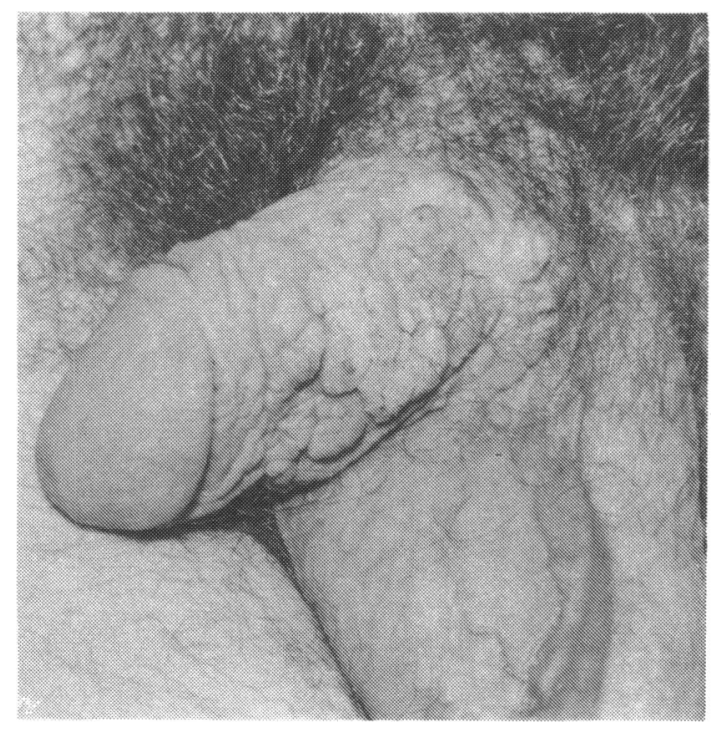

Address for reprints: Dr P D Simmons, Department of Genitourinary Medicine, Eastem Hospital, Homerton Grove, Homerton, London E9 6BY

Accepted for publication 16 December 1985

\section{Case report}

A 29 year old man presented to hospital in 1975 complaining of penile warts. $\mathrm{He}$ was treated with

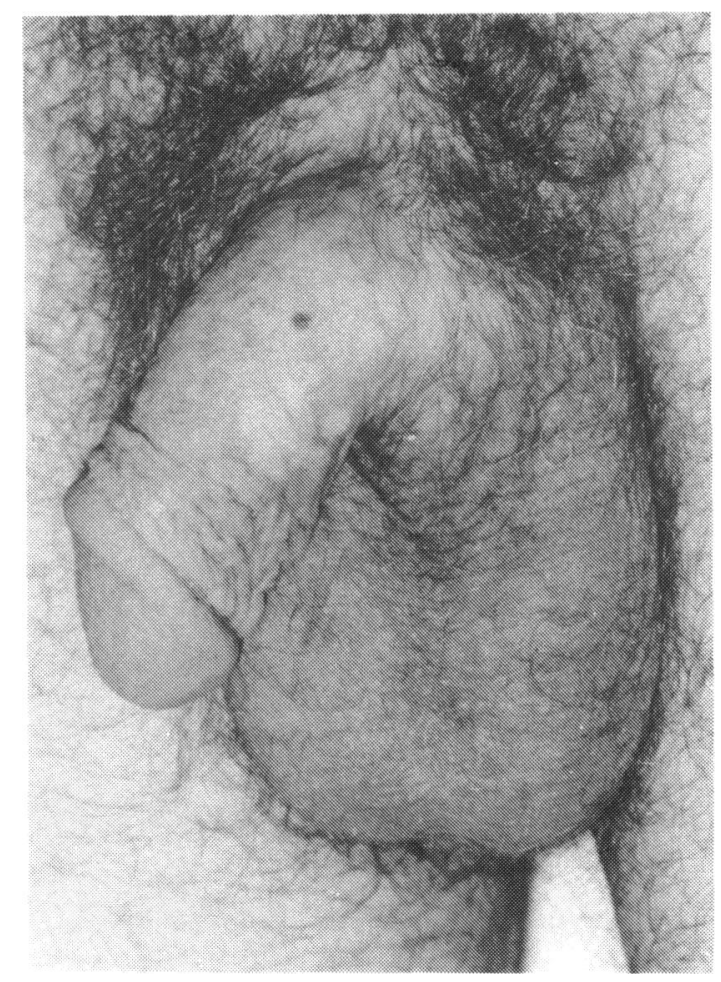

FIG 2 Appearance 12 months after scissor excision of warts. 
repeated applications of podophyllin paint and 5fluorouracil cream, but with little effect. In 1979 a moderately differentiated papillary transitional cell carcinoma was removed from his bladder. Check cystoscopies have since yielded normal results. His penile warts persisted, however, and he became depressed and separated from his wife because of the problem. His family doctor referred him for a second opinion before the proposed removal of the warts by diathermy and skin grafting of the denuded area.

On examination in January 1984, he had florid keratinised warts on the penile shaft, which extended on to the pubic skin (fig 1). The glans penis, urinary meatus, and anus were spared, but he had warts on both hands.

All the warts were excised with sharp-pointed scissors after subcutaneous infiltration of normal saline beneath the lesions. The wounds were covered with oxidised regenerated cellulose (Surgicel) and paraffin gauze. The patient was discharged seven days later. He required no postoperative analgesia and only diazepam $30 \mathrm{mg}$ a day to control his agitated depresson. No recurrences of warts were detected during 12 months follow up (fig 2).

\section{Discussion}

Scissor excision has an important role in the management of severe anorectal warts. It enables patients to be discharged sooner than after electrocautery, ${ }^{12}$ which tends to traumatise and scar the anal skin and causes postoperative pain. Treatments for penile warts are legion and use cytotoxic agents or ablative measures. Scissor excision is another possible treatment, which allows the maximum preservation of normal tissue.

\section{References}

1. Thomson JPS, and Grace RH. The treatment of perianal and anal condylomata acuminata: a new operative technique. $J$ Roy Soc Med 1978;71:180-5.

2. Gollock JM, Slatford K, Hunter JM. Scissor excision of anogenital warts. British Journal of Venereal Diseases 1982; 58:400-1. 